Tersedia Online di http://journal.unismuh.ac.id/index.php/otoritas

Otoritas : Jurnal Ilmu Pemerintahan, 6 (1), April 2016, 28-41

\title{
Peran Pemerintah Daerah dalam Pelaksanaan Penataan Pedagang Kaki Lima di Pasar Minasamaupa Kabupaten Gowa
}

\author{
Handam*), Muchlas M. Tahir \\ Program Studi Ilmu Pemerintahan, Fakultas Ilmu Sosial dan Ilmu Politik, Universitas \\ Muhammadiyah Makassar, Jalan Sultan Alauddin No.259, Makassar, Indonesia, 90221
}

Diterima : 15 Januari 2016; Disetujui : 27 Maret 2016; Dipublikasikan 14 April 2016

\begin{abstract}
The aim of research to determine the role of local government and the factors that influence the local government's role in the implementation of the arrangement of street vendors in the Market Minasamaupa Gowa. This type of research is descriptive qualitative research and type of research is a case study, while the data collection techniques used is observation, interview and documentation. The results of this study indicate that the arrangement of street merchants realized well enough where most merchants do not go out to sell outside the market because it has been relocated into the market. Efforts are being made to the arrangement of the place of business, guidance and supervision. The factors supporting the implementation of the arrangement of the vendors that their Gowa District Regulation No. 5 of 2009 on Management and Development Street Vendors and inhibiting factors, namely the low participation in complying with existing regulations.
\end{abstract}

Keywords: the role of local government; planning street vendors; market

\begin{abstract}
Abstrak
Tujuan penelitian untuk mengetahui peran pemerintah daerah dan faktor-faktor yang mempengaruhi peran pemerintah daerah dalam pelaksanaan penataan pedagang kaki lima di Pasar Minasamaupa Kabupaten Gowa. Jenis penelitian yang digunakan adalah penelitian deskriptif kualitatif dan tipe penelitian adalah studi kasus, sedangkan teknik pengumpulan data yang digunakan adalah observasi, wawancara dan dokumentasi. Hasil penelitian ini menunjukkan bahwa penataan pedangang kaki lima cukup terealisasi dengan baik dimana sebagian besar pedagang tidak lagi berjualan di luar pasar karena telah direlokasi ke dalam pasar. Upaya yang dilakukan yakni melakukan penataan tempat usaha, pembinaan dan pengawasan. Adapun faktor pendukung dalam pelaksanaan penataan pedagang kaki lima tersebut yaitu adanya Peraturan Daerah Kabupaten Gowa Nomor 5 Tahun 2009 Tentang Penataan dan Pembinaan Pedagang Kaki Lima dan faktor penghambat yaitu rendahnya partisipasi dalam mematuhi peraturan yang ada.
\end{abstract}

Kata kunci : peran pemerintah daerah; penataan pedagang kaki lima; pasar

Cara Penulisan Sitasi : Handam, H., Tahir, M.M. (2016). Peran Pemerintah Daerah dalam Pelaksanaan Penataan Pedagang Kaki Lima di Pasar Minasamaupa Kabupaten Gowa. Otoritas : Jurnal Ilmu Pemerintahan, 6 (1), 28-41

${ }^{*}$ Penulis Korespondensi.

E-Mail : handamramani@ymail.com

Copyright (C) 2016, Otoritas : Jurnal Ilmu Pemerintahan, p-ISSN: 2088-3706, e-ISSN: 2502-9320 
Tersedia Online di http://journal.unismuh.ac.id/index.php/otoritas

Otoritas : Jurnal Ilmu Pemerintahan, 6 (1), April 2016, 29

\section{Pendahuluan}

Pembangunan adalah suatu proses perubahan dari sesuatu kondisi yang kurang baik ke arah yang lebih baik atau pembangunan merupakan suatu proses perubahan dari suatu kondisi nasional ke kondisi nasional yang lain yang harus dinilai lebih baik dari keadaan sebelumnya. Pembangunan mengandung berbagai makna baik dari segi ekonomi, sosial, politik dan budaya yang kesemuanya mengandung arti masing-masing.

Begitu halnya juga pembangunan di tiap wilayah atau daerah, di dalam wilayah Negara Kesatuan Republik Indonesia pembangunan dilaksanakan secara terstruktur, baik dari pusat-pusat kota sampai kepada daerah-daerah pedesaan yang semuanya bertujuan untuk meningkatkan harkat dan martabat kehidupan masyarakat kearah yang lebih baik.

Menurut Sedarmayanti (2010), Penyelenggaraan pembangunan yang baik dalam setiap daerah juga tidak lepas dari kinerja para pegawai negeri sipil, semakin baik kinerja pegawai negeri sipil di setiap daerah maka pembangunan di daerah tersebut akan semakin maju dan berkembang, dimana kinerja di definisikan sebagai catatan mengenai out come yang dihasilkan dari suatu aktivitas tertentu, selama kurun waktu tertentu pula (performance is defined as the record of outcomes produced on a specific job function or activity during a specific time period).

Begitupun halnya dalam bidang pembanguan ekonomi kemasyarakatan, masyarakat juga diharapkan ikut berpartisipasi dalam pembangunan kota/ daerah melalui lembaga-lembaga sosial ekonomi kemasyarakatan, dan berusaha untuk meningkatkan derajat kehidupan masyarakat seperti halnya di Kabupaten Gowa khususnya di Pasar Minasamaupa dengan semakin banyaknya pertumbuhan gerakan ekonomi kemasyarakatan, di berbagai sudut kehidupan masyarakat seperti halnya dalam bidang usaha, khususnya pedagang kaki lima atau sektor informal.

Masalah pedagang kaki lima sendiri, tidak kunjung selesai di setiap daerah di Indonesia khususnya di Pasar Minasamaupa Kabupaten Gowa. Permasalahan ini muncul setiap tahun dan terus saja berlangsung tanpa ada solusi yang tepat dalam pelaksanaannya. Keberadaan pedagang kaki lima kerap dianggap ilegal karena menempati ruang publik dan tidak sesuai dengan visi kota yang sebagian besar menekankan aspek kebersihan, keindahan dan kerapihan kota. Oleh karena itu, pedagang kaki lima seringkali menjadi target utama kebijakan-kebijakan Pemerintah Daerah, seperti penggusuran karena kehadiran pedagang kaki lima tersebut sering dikaitkan dengan dampak negatif bagi lingkungan perkotaan, dengan munculnya kesan buruk, kotor, kumuh dan tidak tertib.

Berdasarkan Peraturan Daerah Kabupaten Gowa Nomor 5 Tahun 2009 Tentang Penataan dan Pembinaan Pedagang Kaki Lima, upaya Pemerintah Kabupaten Gowa dalam rangka mengatur keberadaan pedagang kaki lima adalah melalui kegiatan penataan lokasi usaha bagi pedagang kaki lima, pengaturan pemberian perizinan, dan pengaturan mengenai pemberian sanksinya serta senantiasa melaksanakan pembinaan, penyuluhan dan pengawasan sehingga mereka dapat mengembangkan usaha dalam meningkatkan kesejahteraannya serta diharapkan akan menunjang pertumbuhan perekonomian daerah dari sektor informal.

Dengan demikian, Pemerintah kota menganggap kebijakan penataan tersebut merupakan tindakan yang terbaik bagi pedagang kaki lima dan memudahkan pedagang kaki lima. Karena dengan adanya kios-kios yang disediakan pemerintah, pedagang tidak perlu membongkar muat dagangannya. Selain itu, pemerintah juga akan memperhatikan aspek promosi, 
berjualan di sepanjang jalan dan meninggalkan BTC. dihadapkan pada beberapa kendala diantaranya penertiban pedagang kaki lima masih dihadapkan pada kendala perasaan atau emosional. Disisi lain, jumlah pedagang kaki lima di Kota Batu tiap tahun terus membengkak sehingga Satpol PP mengalami kesulitan untuk melakukan penertiban.

Selanjutnya penelitian Dewi dan Yunuardi (2013) implementasi kebijakan penataan pedagang kaki lima di kawasan Malioboro masih terdapat beberapa kelemahan yang sangat mendasar antara lain instrument pendukung peraturan yang tidak lengkap, permasalahan mengenai penentuan lokasi usaha pedagang kaki lima, banyaknya pedagang kaki lima yang melakukan pelanggaran terkait lebar dan tinggi dagangan, pemberian surat izin pedagang kaki lima yang sudah terhenti selama 2 tahun terakhir, pelanggaran pedagang kaki lima di Malioboro dinilai masih cukup tinggi. Faktor pendukung implementasi penataan pedagang kaki lima yaitu sumber daya manusia maupun sumber daya anggaran yang memadai, dan adanya sikap dukungan positif implementor kebijakan dan efisiensi birokrasi.

Kadangkala keberadaan Pedagang Kaki Lima tersebut menimbulkan ketidaknyamanan terhadap jalannya lalu lintas disekitar. Pemerintah daerah dalam hal ini mempunyai kewenangan mengatur permasalahan tersebut untuk mewujudkan Pemerintahan yang Baik (Good Governance) sesuai dengan asas-asas penyelenggaraan Pemerintahan yang Baik (Erlinda, dkk. 2014).

Kemudian Penelitian Ahkam (2015) yaitu Program Penataan Pedagang Kaki Lima (PKL) dI Wilayah Perkotaan (Studi Pada Pemerintah Daerah Kabupaten Bondowoso) menunjukkan pengelolaan yang dilaksanakan oleh Pemerintah Kabupaten Bondowoso melalui Disperindag dan dibantu Kantor Satuan Polisi Pamong Praja dalam memelihara ketentraman dan ketertiban di wilayah perkotaan. Upaya pengelolaan yang dilakukan Pemerintah Daerah dengan menempatkan PKL di suatu tempat yang strategis yang tujuannya untuk menertibkan dan menata agar tidak menggunakan fasilitas umum, selain itu juga lokasi tersebut tidak jauh dari pusat keramaian dan dapat dijangkau oleh masyarakat sekitar. Program penataan PKL di Kabupaten Bondowoso sudah baik, tetapi belum maksimal. dalam program penataan yang dilakukan masih terdapat berbagai hambatan-hambatan baik dari internal maupun eksternal, sehingga keinginan pemerintah untuk mewujudkan kota yang rapi, bersih, nyaman dan aman belum dapat tercapai.

Berdasarkan uraian dari beberapa penelitian terdahulu yang telah dijabarkan. Maka penelitian ini diarahkan untuk mengetahui Peran Pemerintah Daerah dalam Pelaksanaan Penataan Pedagang Kaki Lima di Pasar Minasamaupa Kabupaten Gowa dan faktor-faktor yang mempengaruhi Peran Pemerintah Daerah dalam Pelaksanaan Penataan Pedagang Kaki Lima di Pasar Minasamaupa. Penelitian ini memiliki perbedaan dari segi fokus yaitu peran pemerintah daerah secara menyeluruh meliputi implementasi peraturan daerah berserta faktor pendukung dan penghambat selain itu lokus penelitian ini juga memiliki perbedaan dari penelitian sebelumnya yaitu di Pasar Minasamaupa Kabupaten Gowa.

\section{Metode Penelitian}

Menurut Sugiyono (2013), Metode penelitian pada dasarnya merupakan cara ilmiah untuk mendapatkan data dengan tujuan dan kegunaan tertentu. Penelitian ini dilakukan di Pasar Minasamaupa Kabupaten Gowa. Jenis penelitian yang akan dilakukan adalah penelitian kualitatif, artinya suatu jenis penelitian yang berusaha memberikan penjelasan dengan gambaran mengenai berbagai macam data yang telah dikumpulkan dari objek penelitian yang berkaitan dengan Peran Pemerintah Daerah dalam Pelaksanaan 
Tersedia Online di http://journal.unismuh.ac.id/index.php/otoritas

Otoritas : Jurnal Ilmu Pemerintahan, 6 (1), April 2016, 30

pemasaran, bimbingan pelatihan, dan kemudahan modal usaha.

Tujuan kebijakan pada prinsipnya adalah melakukan intervensi. Oleh karena itu, implementasi kebijakan sebenarnya adalah tindakan (action) intervensi itu sendiri. Keberhasilan suatu implementasi kebijakan publik ditentukan oleh tingkat implementability kebijakan itu sendiri, yang terdiri atas content of policy dan context of policy. Content of policy menurut Grindle adalah : (a) Interest affected (kepentingankepentingan yang mempengaruhi), (b) Type of benefit(tipe manfaat), (c) Extent of change envision (derajat perubahan yang ingin dicapai), (d) Site of decision making (letak pengambilan keputusan), (e) Program implementer (pelaksanaan program), (f) Resource committed (sumber daya yang digunakan). Context of Policy menurut Grindle adalah: (a) Power, InterestandSrategyofactor involved (kekuasaan, kepentingan-kepentingan, dan strategi dari kepentingan yang terlibat), (b) Institution and regime characteristic (karakteristik lembaga dan rezim yang berkuasa), (c) Compliance and Responsiveness (tingkat kepatuhan dan adanya respon dari pelaksana). (Nugroho 2009).

Pedagang kaki lima disebut juga pedagang liar atau pedagang eceran yaitu pedagang yang berjualan di pinggirpinggir jalan, emperan toko-toko, di halaman bangunan pasar, lapangan-lapangan terbuka dan tempat-tempat lain yang sifatnya sementara dan belum mendapat izin resmi dari pemerintah.

Menurut Karafir (2007) pedagang kaki lima adalah pedagang yang berjualan di suatu tempat umum seperti tepi jalan, taman-taman, emper-emper toko dan pasar-pasar tanpa atau adanya izin usaha dari pemerintah. Kemudian sesuai Peraturan Daerah Kabupaten Gowa Nomor 5 Tahun 2009 tentang Penataan dan Pembinaan Pedagang Kaki Lima, yang dimaksud dengan pedagang kaki lima adalah orang yang melakukan usaha dagang dan atau jasa di tempat umum, yaitu tepi-tepi jalan umum, lapangan serta tempat lain di atas tanah yang ditetapkan oleh Bupati.
Penataan pedagang kaki lima dalam Peraturan Daerah tersebut mempunyai dua peranan yang sangat penting, yaitu satu sisi merupakan perlindungan dan pengakuan terhadap keberadaan pedagang kaki lima di Kabupaten Gowa, sedangkan di sisi lainnya Peraturan Daerah ini merupakan dasar hukum yang kuat bagi Pemerintah Daerah untuk melakukan fasilitasi/pembinaan, pengaturan dan penertiban terhadap pedagang kaki lima.

Peranan (role) merupakan proses dinamis kedudukan (status). Apabila seseorang melaksanakan hak dan kewajibannya sesuai dengan kedudukannya, dia menjalankan suatu peranan. Perbedaan antara kedudukan dengan peranan adalah untuk kepentingan ilmu pengetahuan. Keduanya tidak dapat dipisah-pisahkan karena yang satu tergantung pada yang lain dan sebaliknya (Soekanto, 2009).

Levinson dalam Soekanto (2009) mengatakan peranan mencakup tiga hal, antara lain : (1) Peranan meliputi normanorma yang dihubungkan dengan posisi atau tempat seseorang dalam masyarakat. Peranan dalam arti ini merupakan rangkaian peraturan-peraturan yang membimbing seseorang dalam kehidupan bermasyarakat. (2) Peranan merupakan suatu konsep tentang apa yang dapat dilakukan oleh individu dalam masyarakat sebagai organisasi. (3) Peranan juga dapat dikatakan sebagai perilaku individu yang penting bagi struktur sosial masyarakat.

Bebagai kajian tentang penataan PKL diuraikan dari hasil penelitian terdahulu seperti penelitian Evita (2013) hasil dari penelitian menunjukkan bahwa implementasi kebijakan penataan pedagang kaki lima pada Batu Tourism Center merupakan unsuccessful implementation (implementasi yang tidak berhasil). Hal ini disebabkan karena beberapa permasalahan dan kendala sehingga sebagian besar pedagang kaki lima memilih kembali 
Tersedia Online di http://journal.unismuh.ac.id/index.php/otoritas

Otoritas : Jurnal Ilmu Pemerintahan, 6 (1), April 2016, 32

Penataan Pedagang Kaki Lima di Pasar Minasamaupa Kabupaten Gowa. Peneliti menggunakan tipe penelitian studi kasus yaitu penelitian yang mengeksplorasi suatu masalah dengan batasan terperinci dan menyertakan berbagai sumber informasi dengan menggambarkan tentang situasi atau fenomena sosial secara detail yang bertujuan mendeskripsikan sesuatu secara jelas (deskriptif kualitatif).

\section{Hasil dan Pembahasan}

\subsection{Peran Pemerintah Daerah dalam penataan pedagang kaki lima di Pasar Minasamaupa}

Peran pemerintah daerah dalam penataan pedagang kaki lima di Pasar Minasamaupa Kabupaten Gowa terjabarkan dalam beberapa poin yaitu :

\section{Adanya penataan tempat usaha}

Penataan tempat usaha yang dilakukan oleh Pemerintah Daerah Kabupaten Gowa dalam melaksanakan penataan pedagang kaki lima yang telah ditetapkan dalam Peraturan Daerah Kabupaten Gowa Nomor 5 Tahun 2009 bertujuan agar pedagang kaki lima tidak menempati lokasi yang dapat mengganggu ketertiban dan tata ruang kota.

Pemerintah Daerah bertujuan untuk mewujudkan alokasi tempat usaha yang layak untuk memberikan kesempatan berusaha bagi pedagang serta menciptakan lingkungan yang indah dan bersih, namun juga dapat memberdayakan keberadaan pedagang kaki lima untuk menopang ekonomi daerah.

Berikut wawancara dengan Kepala Dinas Perindustrian dan Perdagangan Kabupaten Gowa yang mengatakan bahwa:

"Pembangunan tempat usaha merupakan wujud kepedulian pemerintah dalam hal menyejahterakan pedagang. Jadi pada dasarnya para pedagang tidak perlu khawatir kalau mereka tidak akan bisa melanjutkan usahanya, karena kami dari Pemerintah sudah menyiapkan tempat usaha berupa kios-kios sebagai tempat usaha mereka". (Wawancara. TM, 15 Juli 2015).

Berdasarkan hasil wawancara di atas menunjukkan bahwa penataan pedagang kaki lima yang dilakukan oleh Dinas Perindustrian dan Perdagangan Kabupaten Gowa sebagai penegak Peraturan Daerah merupakan wujud kepedulian Pemerintah Daerah dalam mewujudkan tempat usaha yang nyaman, aman dan produktif dalam menyejahterahkan masyarakat

Senada wawancara dengan Kepala Badan Satuan Polisi Pamong Praja Kabupaten Gowa yang mengatakan bahwa:

"Kami melaksanakan penataan

di Pasar Minasamaupa sebagai salah satu tugas kami dalam penegakan Perda. Penataan yang dilaksanakan berdasarkan surat perintah oleh $\mathrm{Bu}$ pati. Penegakan Peraturan Daerah ini tidak hanya dilakukan dengan penertiban, tetapi pedagang diberikan tempat usaha dan disewakan sesuai kemampuan mereka". (Wawancara. HH, 10 Juli 2015).

Berdasarkan hasil wawancara di atas menunjukkan bahwa penataan pedagang kaki lima di Pasar Minasamaupa yang dilakukan Badan Satuan Polisi Pamong Praja Kabupaten Gowa sesuai Peraturan Daerah dan surat perintah oleh Bupati mengenai penataan pedagang kaki lima. Penataan pedagang kaki lima di Pasar Minasamaupa dilakukan dengan memberikan tempat usaha yang layak bagi pedagang sebagai wujud kepedulian Pemerintah Daerah dalam hal menyejahterakan pedagang.

Berikut wawancara dengan salah satu pedagang di Pasar Minasamaupa yang mengatakan bahwa:

"Kebijakan pemerintah dalam menyiapkan tempat usaha bagi pedagang sudah baik. Pedagang didata kemudian diberikan tempat usaha yang disewa berupa kios-kios sesuai dengan kemampuan pedagang. Akan

Copyright (C) 2016, Otoritas : Jurnal Ilmu Pemerintahan, p-ISSN: 2088-3706, e-ISSN: 2502-9320 
Tersedia Online di http://journal.unismuh.ac.id/index.php/otoritas

Otoritas : Jurnal Ilmu Pemerintahan, 6 (1), April 2016, 33

tetapi mengenai kebersihan dan keamanan perlu juga di perhatikan". (Wawancara. DN, 20 Juli 2015).

Berdasarkan hasil wawancara di atas menunjukkan bahwa penataan pedagang kaki lima yang dilakukan oleh Pemerintah Daerah dalam mewujudkan keserasian antara kehidupan manusia dengan lingkungannya, keserasian dengan pertumbuhan dan perkembangan kawasan perkotaan telah dilaksanakan dengan baik. Pemerintah Daerah Kabupaten Gowa berharap agar Pasar Minasa dapat memberikan kesempatan berusaha bagi pedagang dengan tempat usaha yang bersih, indah, tertib dan aman serta sarana dan prasarana yang memadai.

Berikut wawancara dengan salah satu pengunjung di Pasar Minasamaupa mengatakan bahwa:

"Relokasi pedagang yang ada di Pasar Minasamaupa untuk pindah berjualan masuk ke Pasar cukup baik karena kemacetan akibat banyaknya kendaraan masyarakat yang singgah untuk berbelanja kini sudah berkurang. Resiko kecelakaan juga dapat minimalisir, sehingga kami pengguna jalan sudah tidak was-was saat melintasi wilayah ini". (Wawancara. AA, 21 Juli 2015).

Berdasarkan hasil wawancara di atas menujukkan bahwa masyarakat merasa senang dengan adanya kebijakan pemerintah tersebut dalam merelokasi pedagang ke tempat yang aman. Selain tidak lagi menimbulkan kesan tempat yang kurang baik di masyarakat, namun juga akan mengurangi kemacetan dari semakin padatnya kendaraan yang melewati wilayah tersebut.

Senada wawancara dengan anggota Badan Satuan Polisi Pamong Praja Kabupaten Gowa yang mengatakan bahwa:

"Kenyataan di lapangan masyarakat sudah merasa senang karena ketentraman sudah dapat dirasakan dan pembeli juga merasa senang karena pengelompokkan penjual sudah dilakukan".

(Wawancara. DS, 10 Juli 2015).

Berdasarkan hasil wawancara di atas menunjukkan bahwa pelaksanaan penataan pedagang kaki lima di Pasar Minasamaupa yang dilakukan oleh Pemerintah Daerah Kabupaten Gowa telah mendapat reaksi yang positif dari masyarakat yang melihat dan merasakan suasana Pasar Minasamaupa yang sudah cukup rapi dibanding kondisi sebelumnya yang semrawut dan memberikan kemudahan kepada pembeli dalam berbelanja kebutuhan sehari-hari karena pengelompokkan penjual tersebut.

\section{Pembinaan Pedagang}

Penataan pedagang kaki lima yang dilakukan diharapkan tidak hanya menjadi eksistensi Pemerintah Daerah dalam menjalankan Peraturan Daerah dengan baik, namun Pemerintah Daerah sebagai perpanjangan tangan dari Pemerintah Pusat harus memberikan pembinaan dan penyuluhan kepada pedagang untuk kepentingan pengembangan usaha dan peningkatan kesejahteraan pedagang kaki lima. Pemerintah Daerah Kabupaten Gowa sebagai dinamisator berperan melalui pemberian bimbingan dan pengarahan secara intensif dan efektif kepada masyarakat khususnya pedagang kaki lima dengan memberikan pelatihan dan pembinaan.

Berikut wawancara dengan Kepala Dinas Perindustrian dan Perdagangan Kabupaten Gowa yang mengatakan bahwa:

"Disperindag melakukan sosialisasi dan rapat bersama dengan pedagang untuk penempatan kioskios untuk melakukan pengelompokkan pedagang sesuai jenis jualan mereka dan diberikan hak sewa tempat jualan untuk setiap pedagang". (Wawancara. TM, 15 Juli 2015).

Berdasarkan hasil wawancara di atas menunjukkan bahwa sebelum merelokasi pedagang kaki lima di Pasar Minasamaupa, Pemerintah Daerah mala- 
Tersedia Online di http://journal.unismuh.ac.id/index.php/otoritas

Otoritas : Jurnal Ilmu Pemerintahan, 6 (1), April 2016, 34

kukan pertemuan dan sosialisasi kepada pedagang tentang penataan tempat usaha agar pedagang tidak merasa dirugikan karena adanya penataan tersebut.

Demikian pula keterangan yang diungkapkan oleh salah satu pedagang di Pasar Minasamaupa yang mengatakan bahwa:

"Kami diberikan kios sesuai jenis dagangan yang kami jual yang dikenakan biaya sebesar Rp.1.000/ hari atau lebih. Pembinaan yang diberikan berupa pemilihan jenis jualan yang layak untuk kami jual ke konsumen". (Wawancara. DT, 20 Juli 2015).

Berdasarkan hasil wawancara di atas menunjukkan bahwa Pemerintah Daerah dalam hal ini Dinas Perindustrian dan Perdagangan Kabupaten Gowa melakukan pembinaan kepada pedagang kaki lima dengan memberikan sosialisasi penempatan dan pengelompokkan pedagang berdasarkan jenis jualan mereka. Pengelompokkan tersebut dilakukan agar memudahkan pengawasan dan menjadikan Pasar Minasamaupa agar tertata dengan baik.

Berikut wawancara dengan salah satu pengunjung di Pasar Minasamaupa yang mengatakan bahwa:

"Adanya pengelompokkan
pedagang yang dilakukan
pemerintah sangat memudahkan
pembeli mencari bahan makanan
yang mereka butukhkan. Dan
keberadaan pedagang yang tidak
lagi berjualan di luar otomatis men-
gurangi resiko keselamatan peda-
gang dan pembeli saat melakukan
transaksi jual beli". (Wawancara. MK,
21 Juli 2015).
Berdasarkan hasil wawancara di
menunjukkan bahwa masyarakat
rasa senang dengan kondisi Pasar Mi-
amaupa yang sudah bagus dan peda-
guga sudah dapat ditata dengan baik.
yang biasa terjadi di pagi maupun sore

hari sudah berkurang karena relokasi pedagang ke dalam Pasar yang biasanya menempati ruas-ruas jalan.

Berikut wawancara dengan Kepala Bidang Perdagangan Dinas Perindustrian dan Perdagangan Kabupaten Gowa yang mengatakan bahwa:

"Pemerintah Daerah menyiapkan sarana yang ditetapkan kurang lebih 933 kios. Sehingga pedagang kaki lima tidak lagi bertebaran lagi dipinggir jalan dan tidak menggangu lalu lintas. Disamping itu Pemerintah Daerah juga menyiapkan sarana bongkar muat untuk pedagangpedagang yang datang dari luar kota yang jumlahnya sekitar 1.500 pedagang." (Wawancara. HMR, 15 Juli 2015).

Berdasarkan hasil wawancara di atas menunjukkan bahwa Pemerintah Daerah Kabupaten Gowa berupaya menyiapkan sarana dan prasarana yang dapat memberikan kenyamanan bagi masyarakat dalam melakukan jual beli tanpa mengganggu arus lalu lintas. Namun, jumlah kios yang disiapkan oleh pemerintah tidak sebanding dengan jumlah pedagang yang ada sehingga masih ada pedagang yang menepati ruasruas jalan di sekitar wilayah tersebut.

Setiap peraturan yang dikeluarkan oleh pemerintah tidak sepenuhnya dapat diterima oleh masyarakat khususnya pedagang kaki lima yang menganggap peraturan tersebut akan mengurangi bahkan menghilangkan mata pencaraharian mereka. Sebagaimana wawancara dengan salah satu pedagang di Pasar Minasamaupa yang mengatakan bahwa:

"Kami berjualan di tempat ini karena kios yang ada di Pasar Minasamaupa itu sudah banyak yang menempati. Kami berjualan di sini karena dagangan kami cepat laku dibanding bejualan di dalam pasar yang lokasinya berada di dalam". (Wawancara. DT, 20 Juli 2015).

Berdasakan hasil wawancara di atas

Copyright (C) 2016, Otoritas : Jurnal Ilmu Pemerintahan, p-ISSN: 2088-3706, e-ISSN: 2502-9320 
Tersedia Online di http://journal.unismuh.ac.id/index.php/otoritas

Otoritas : Jurnal Ilmu Pemerintahan, 6 (1), April 2016, 35

menunjukkan bahwa pedagang menilai lokasi Pasar Minasamaupa yang disiapkan oleh pemerintah tidak sesuai kebutuhan pedagang karena hasil yang didapatkan itu jauh berbeda dengan hasil yang didapat ketika berjualan di luar.

Senada wawancara dengan pedagang yang lain di Pasar Minasamaupa yang mengatakan bahwa:

"Kebijakan pemerintah dalam merelokasi pedagang untuk masuk ke Pasar sudah tepat walaupun untung yang kami berbeda ketika saya berjualan di luar. Karena pembeli kadang malas masuk ke Pasar yang jauh ke dalam". (Wawancara. DN, 20 Juli 2015).

Berdasarkan hasil wawancara di atas menunjukkan bahwa untuk dapat menjual dagangannya maka pedagang kaki lima harus bisa diberikan sarana dan prasarana yang baik karena jumlah pedagang dan tempat berjualan (kios-kios) di Pasar Minasamaupa masih belum sesuai sehingga masyarakat mengharapkan adanya tempat usaha yang layak sehingga baik pedagang maupun para pengunjung dapat menikmati suasana yang menyenangkan bisa ada di tempat tersebut.

Berikut wawancara dengan Kepala Dinas Perindustrian dan Perdagangan Kabupaten Gowa yang mengatakan bahwa:

"Memang masih ada beberapa pedagang kaki lima yang datang berjualan di Pasar Minasamaupa tidak memiliki kemampuan atau keterampilan untuk pekerjaan lain selain menjadi pedagang kaki lima, dan kami dari selaku Pemerintah Daerah bekerjasama untuk melakukan program pembinaan bagi pedagang supaya diharapkan dari program pembinaan ini, para pedagang kaki lima mempunyai kemampuan dan keterampilan untuk mendapatkan atau menciptakan pekerjaan lain selain menjadi pedagang kaki lima". (Wawancara. TM, 15 Juli 2015).
Berdasarkan hasil wawancara di atas menunjukkan bahwa pentingnya peran dari Pemerintah Daerah Kabupaten Gowa untuk melakukan pembinaan yang baik kepada para pedagang kaki lima di Pasar Minasamaupa agar para pedagang ini mendapatkan kemampuan dan keterampilan untuk mendapatkan bahkan menciptakan lapangan kerja baru yang tentunya yang dapat menguntungkan bagi mereka.

Dalam proses pelaksanan penataan pedagang kaki lima, upaya yang dilakukan oleh pemerintah antara lain sosialisasi informasi mengenai rencana pentaan, membangun tempat usaha bagi pedagang kaki lima dan menertibkannya. Kegiatankegiatan yang dilakukan berdasarkan rencana yang telah ditetapkan sebelumnya oleh tim operasional penataan pedagang kaki lima. Sebagaimana wawancara dengan Kepala Dinas Perindustrian dan Perdagangan Kabupaten Gowa yang mengatakan bahwa:

"Sebelum melakukan relokasi, pemerintah terlebih dahulu melakukan upaya persuasif dengan cara mengadakan sosialisasi dengan para pedagang kaki lima yang dilakukan oleh tim operasional dan dikemukakan lokasi dan tempattempat yang telah pemerintah tetapkan". (Wawancara. TM, 15 Juli 2015).

Berdasarkan hasil wawancara di atas menunjukkan bahwa penataan pedagang kaki lima di Pasar Minasamaupa yang dilakukan oleh Pemerintah Daerah dalam hal ini Dinas Perindustrian dan Perdagangan Kabupaten Gowa selalu melakukan upaya-upaya persuasif untuk menciptakan keamanan dan ketenteraman di tengah masyarakat.

Demikian pula wawancara dengan Kepala Bidang Penegakan Perundangundangan Badan Satuan Polisi Pamong Praja Kabupaten Gowa yang mengatakan bahwa:

"Setiap melaksanakan pen- 
Tersedia Online di http://journal.unismuh.ac.id/index.php/otoritas

Otoritas : Jurnal Ilmu Pemerintahan, 6 (1), April 2016, 36

ertiban kami tidak hanya melakukan tindakan secara rensponsif kepada pedagang namun harus ada solusi yang diberikan. Kami melakukan pendataan kepada pedagang kemudian kami berikan kios-kios sebagai tempat usaha mereka". (Wawancara. HS, 10 Juli 2015).

Berdasarkan hasil wawancara di atas menunjukkan bahwa dalam menjamin kelestarian dan kelangsungan hidup bagi pedagang kaki lima di Pasar Minasamaupa, Pemerintah Daerah Kabupaten Gowa tidak hanya memberikan penataan kepada pedagang kaki lima saja yang melakukan kesalahan namun juga memberikan solusi untuk mengatasi permasalahan tersebut dengan memberikan lahan atau tempat untuk berjualan dan melakukan sosialisasi kepada pihak pedagang kaki lima demi menciptakan kondisi yang tertib demi kepentingan umum.

Dari penyataan di atas, Kepala Bidang Penegakan Perundang-undangan Badan Satuan Polisi Pamong Praja Kabupaten Gowa menambahkan bahwa:

"Pemerintah Daerah selaku Pembina dari para pedagang untuk dapat menimbulkan kesadaran akan pentingnya keteraturan dalam mencari nafkah melalui usaha sehingga dapat menimbulkan harmonisasi yang baik antara penjual, pemerintah dan masyarakat. Serta terciptanya ketenteraman dan ketertiban umum bagi pengguna jalan". (Wawancara. HS, tanggal 10 Juli 2015).

Berdasarkan hasil wawancara di atas menunjukkan bahwa upaya yang dilakukan Pemerintah Daerah dalam pelaksanaan penataan pedagang kaki lima untuk memberikan kesadaran kepada pedagang dalam mematuhi aturan yang ada sehingga masyarakat luas dapat merasakan kenyamanan saat melakukan transaksi jual beli karena ketenteraman dan ketertiban yang tetap dijaga oleh semua pihak.

Pelaksanaan penataan pedagang ka- ki lima dilakukan oleh pemerintah untuk memberikan lokasi tempat usaha pedagang kaki lima yang layak. Adanya suatu kesadaran bahwa pedagang kaki lima tidak dapat diatasi dengan penggusuran merupakan alasan yang melatarbelakangi Pemerintah Daearh Kabupaten Gowa untuk menata pedagang kaki lima dan membangun Pasar Minasamaupa sebagai tempat usaha yang layak bagi pedagang. Sebagaimana wawancara dengan Kepala Badan Satuan Polisi Pomong Praja Kabupaten Gowa yang mengatakan bahwa:

"Pembangunan tempat usaha merupakan bukti bahwa pemerintah tidak akan begitu saja menelantarkan pedagang kaki lima. Jadi pada dasarnya para pedagang kaki lima tidak perlu khawatir kalau mereka tidak akan bisa melanjutkan usahanya, karena kami dari pemerintah sudah menyiapkan tempat usaha yang layak bagi mereka. Dan yang perlu ditekankan adalah bahwa kebijakan penataan pedagang kaki lima bukanlah menggusur, tetapi menata pedagang pada lokasi yang sesuai". (Wawancara. HH, 10 Juli 2015).

Berdasarkan hasil wawancara di atas menunjukkan bahwa pembangunan tempat usaha dimaksudkan oleh pemerintah untuk tetap memberikan kesempatan kepada para pedagang kaki lima dalam menjalankan usahanya. Pemerintah juga berusaha menghilangkan tanggapan para pedagang kaki lima yang selama ini menganggap diri mereka sebagai pihak yang selalu ditelantarkan selama proses penataan pedagang kaki lima. Dengan adanya pembangunan tempat usaha yang baru bagi mereka, maka pemerintah menginginkan para pedagang kaki lima menempati lokasi yang telah ditentukan dan tidak lagi mempergunakan lokasi-lokasi yang melanggar peraturan.

\section{Pengawasan}

Copyright (C) 2016, Otoritas : Jurnal Ilmu Pemerintahan, p-ISSN: 2088-3706, e-ISSN: 2502-9320 
Tersedia Online di http://journal.unismuh.ac.id/index.php/otoritas

Otoritas : Jurnal Ilmu Pemerintahan, 6 (1), April 2016, 37

Dalam melaksanakan penataan pedagang kaki lima Pemerintah Daerah Kabupaten Gowa melakukan pengawasan dengan memberikan nasehat, arahan dan petunjuk kepada pedagang kaki lima untuk melaksanakan kegiatan usaha sesuai dengan peraturan yang ada. Disamping menciptakan lingkungan yang bersih, penciptaan keamanan dan ketertiban juga harus menjadi perhatian Pemerintah Daerah Kabupaten Gowa demi kepentingan umum.

Berikut wawancara dengan Kepala Bidang Penegakan Perundang-undangan Badan Satuan Polisi Pamong Praja Kabupaten Gowa yang mengatakan bahwa:

"Kami membantu Bupati dalam menciptakan keamanan dan ketertiban serta penegakan Peraturan Daerah tentunya akan melaksanakan seluruh program Pemerintah Daerah dalam bidang ketentraman dan ketertiban umum sebagai salah satu urusan wajib Pemerintah Daerah dalam upaya menciptakan situasi yang kondusif dan teratur di tengah masyarakat sehingga pelaksanaan pembangunan dapat berjalan dengan baik sesuai dengan Rencana Strategi Pemerintah Daerah (Renstrada)". (Wawancara. HS, 10 Juli 2015).

Berdasarkan hasil wawancara di atas menunjukkan bahwa Badan Satuan Polisi Pamong Praja Kabupaten Gowa diberikan amanah sesuai dengan tujuannya untuk memberikan keamanan dan ketertiban kapada masyarakat dalam menciptakan situasi yang kondusif dan teratur sesuai dengan Rencana Strategi Pemerintah Daerah (Renstrada).

Senada wawancara dengan anggota Satuan Polisi Pomong Praja Kabupaten Gowa yang mengatakan bahwa:

"Penataan pedagang kaki lima

kami laksanakan berdasarkan perintah yang tentunya untuk memberikan kenyamanan bagi masyarakat dan pedagang itu sendiri". (Wawancara. DS, 10 Juli 2015).
Berdasarkan hasil wawancara di atas menunjukkan bahwa Pemerintah Daerah melaksanakan penataan pedagang kaki lima sesuai dengan peraturan yang ada dan berupaya menciptakan situasi yang kondusif demi memberikan kenyamanan untuk kepentingan masyarakat. Pandangan pedagang kaki lima terhadap pelaksanaan penataan yang dilakukan pemrintah dianggap sebagai upaya untuk mematikan usaha mereka, diskriminatif, bertentangan dengan HAM, dan mengancam keberlangsungan hidup pedagang kaki lima. Sebagaimana wawancara dengan Kepala Badan Satuan Polisi Pamong Praja yang mengatakan bahwa:

"Kendala yang kami hadapi adalah adanya masyarakat heterogen dan masih banyaknya pedagang yang belum memahami aturan yang ada khususnya di bidang penataan dan hubungan kekeluargaan antara pedagang dan petugas merasa hibah akibatnya kami melalaikan tugas pokok serta kesalahan persepsi pedagang dalam memaknai filosofi budaya "Lebih baik mati berdarah daripada mati kelaparan". (Wawancara. HH, 10 Juli 2015).

Berdasarkan hasil wawancara di atas menunjukkan bahwa Pemerintah Daerah telah melaksanakan penataan pedagang kaki lima sesuai dengan peraturan yang ada, namun masih kurangnya pemahaman masyarakat dalam hal ini pedagang kaki lima tentang aturan tersebut sehingga tidak jarang pedagang melakukan upaya apapun demi mempertahankan tempat usaha mereka yang sebenarnya menjadi lokasi yang di larang untuk berjualan. Permasalahan tersebut tentunya juga tidak terlepas dari adanya penegakan peraturan yang baik dilakukan oleh Badan Satuan Polisi Pamong Praja sebagai pembantu Pemerintah Daerah dalam bidang ketentraman. Badan Satuan Polisi Pamong Praja berkewajiban untuk melakukan penataan terhadap pedagang kaki lima yang melanggar peraturan ter- 
Tersedia Online di http://journal.unismuh.ac.id/index.php/otoritas

Otoritas : Jurnal Ilmu Pemerintahan, 6 (1), April 2016, 38

sebut demi menciptakan kepastian hukum bagi masyarakat, melihat tugas Polisi Pamong Praja sebagai penegak Peraturan Daerah.

Berikut wawancara dengan salah satu pengunjung di Pasar Minasamaupa yang mengatakan bahwa:

"Menurut saya pengawasan terhadap tempat usaha pedagang tidak ada sanksi yang tegas dari pemerintah dalam hal ini aparat, sehingga masih ada pedagang yang berjualan di tempat yang tidak sesuai dengan aturan yang ada." (Wawancara. AA, 21 Juli 2015).

Berdasarkan hasil wawancara di atas menunjukkan bahwa pengawasan terhadap pedagang kaki lima yang dilakukan oleh pemerintah tidak memberikan kepuasan terhadap masyarakat mengenai upaya penataan pedagang kaki lima di Pasar Minasamaupa untuk memberikan sanksi yang tegas bagi pedagang yang menyalahi aturan yang ada.

Berikut wawancara dengan pengunjung yang lain di Pasar Minasa yang mengatakan bahwa:

"Keamanan dan ketertiban tentunya tidak terlepas dari aparat keamanan yang harus terus dilakukan termasuk Satuan Polisi Pamong Praja. Dan harus menjamin keadilan bagi semua pihak dalam menegakkan aturan-aturan yang ada". (Wawancara. MK, 21 Juli 2015).

Berdasarkan hasil wawancara di atas menunjukkan bahwa Penegakan Peraturan Daerah terkait penataan pedagang kaki lima dalam mejamin keadilan untuk memberikan kepastian hukum telah dilaksanakan dengan baik oleh Pemerintah Daerah melaui aparat penegak Peraturan Daerah. Penegakan Perda tersebut masyarakat berharap untuk ke depan semua pihak baik pemerintah maupun pedagang dapat saling bekerja sama untuk mempertahankan dan meningkatkan upaya tersebut demi menjadikan Kabupaten Gowa sebagai kota yang tertib, aman dan nyaman.

Berikut wawancara dengan salah satu pengunjung di Pasar Minasamaupa yang mengatakan bahwa:

"Menurut saya, dalam pengawasan yang dilakukan oleh pemerintah terhadap pedagang masih kurang maksimal dalam melaksanakan tugasnya. Karena masih adanya pedagang yang berjualan di pinggir jalan padahal sudah ada tempat yang disediakan di dalam pasar." (Wawancara. AA, 21 Juli 2015).

Berdasarkan hasil wawancara di atas menunjukkan bahwa pengawasan yang dilakukan oleh pemerintah masih kurang terlaksana karena masyarakat menganggap keberadaan pedagang yang berjualan selain di tempat yang disediakan itu sangat mengganggu kenyamanan masyarakat. Tidak hanya pedagang yang ada di sekitar jalan Pasar Minasamaupa, pedagang yang berada di Jalan Syekhyusuf, Jalan Aroepala juga di anggap illegal.

Berikut wawancara dengan Kepala Bidang Penegakan Perundang-undangan Badan Satuan Polisi Pamong Praja Kabupaten Gowa yang mengatakan bahwa:

"Kami tetap memelihara dan menjaga keamanan dan ketertiban agar situasi tetap kondusif sebagai para penjual dapat mencari nafkah dengan aman dan teratur, di lain pihak masyarakat juga dapat memenuhi kebutuhannya dengan puas dan aman karena adanya keteraturan tersebut. Dan sanksi yang diberikan sesuai dengan Standar Operasional Prosedur yang ada serta di dasarkan atas Peraturan Daerah Kabupaten Gowa Nomor 5 Tahun 2009 tentang Penataan dan Pembinaan Pedagang Kaki Lima serta Peraturan Bupati Lainnya". (Wawancara. HS, 10 Juli 2015).

Berdasarkan hasil wawancara di

Copyright (C) 2016, Otoritas : Jurnal Ilmu Pemerintahan, p-ISSN: 2088-3706, e-ISSN: 2502-9320 
Tersedia Online di http://journal.unismuh.ac.id/index.php/otoritas

Otoritas : Jurnal Ilmu Pemerintahan, 6 (1), April 2016, 39

atas menunjukkan bahwa penataan pedagang kaki lima di Pasar Minasamaupa tidak terlepas dari upaya Pemerintah Daerah yang dilakukan oleh Badan Satuan Polisi Pamong Praja Kabupaten Gowa dalam menciptakan situasi tetap kondusif bagi semua pihak dengan memberikan sanksi yang tegas bagi pedagang yang melanggar sehingga ketentraman dan ketertiban dapat tetap terjaga demi kepentingan masyarakat.

\subsection{Faktor-faktor yang mempengaruhi peran Pemerintah Daerah dalam pelaksanaan penataan pedagang kaki lima di Pasar Minasamaupa}

Ada dua faktor yang mempengaruhi peran Pemerintah Daerah dalam pelaksanaan penataan pedagang kaki lima di Pasar Minasamaupa, sebagai mana yang dijabarkan dalam 2 poin berikut :

1. Faktor Pendukung

Berikut wawancara dengan Kepala Bidang Penegakan Peundang-undangan di Badan Satuan Polisi Pamong Praja Kabupaten Gowa yang mengatakan bahwa:

"Penataan pedagang kaki lima yang dilakukan Pemerintah Daerah tidak terlepas karena adanya Peraturan Daerah Nomor 5 Tahun 2009 dan Peraturan-peraturan lainnya yang menjadi rujukan untuk menciptakan tata ruang ataupun tempattempat umum yang bebas dari pedagang-pedagang liar yang menjadi salah satu penyebab kemacetan, kesemtawutan atau dampak lain yang mengganggu masayarakat". (Wawancara. HS, 10 Juli 2015).

Berdasarkan hasil wawancara di atas menunjukkan bahwa faktor yang mendukung pelaksanaan pedagang kaki lima di Pasar Minasamaupa adalah adanya Peraturan Daerah Nomor 5 Tahun 2009 dan Peraturan-peraturan lainnya mengenai pedagang kaki lima, sehingga Pemerintah Daerah dan Instansi terkait mempunyai dasar hukum untuk menin- dak pedagang kaki lima yang menyalahi aturan yang ada.

Realisasi penegakan Peraturan Daerah tersebut juga tidak terlepas karena adanya koordinasi yang baik diantara instansi terkait dalam melaksanakan penataan Pedagang Kaki Lima dalam rangka mewujudkan keamanan, kenyamanan, dan ketertiban di Pasar Minasamaupa.

\section{Faktor Penghambat}

Jumlah pedagang kaki lima yang terus bertambah tentunya harus mendapat perhatian serius dari Pemerintah Daerah dalam menangani permasalahan pedagang kaki lima di Kabupaten Gowa. Selain mengenai aturan lokasi tempat usaha pedagang, rendahnya partisipasi pedagang juga menjadi faktor pengahambat bagi pemerintah untuk menerapkan aturan dalam pelaksanaan penataan pedagang kaki lima di Pasar Minasamaupa. Sebagaimana wawancara dengan Kepala Bidang Perdagangan Dinas Perindustrian dan Perdagangan Kabupaten Gowa yang mengatakan bahwa:

"Dalam penerapan Peraturan mengenai penataan pedagang kaki lima yang kami lakukan, seringkali terkendala karena masih banyak pedagang yang tidak paham bahkan masyarakat kurang peka terhadap aturan yang dibuat oleh pemerintah yang sebenarnya dapat memberikan kenyamanan kepada masyarakat." (Wawancara. HMR, 15 Juli 2015).

Berdasarkan hasil wawancara di atas menunjukkan bahwa kendala yang dihadapi oleh pemerintah dalam melaksanakan penataan pedagang kaki lima di Pasar Minasamaupa yakni minimnya partisipasi masyarakat tentang peraturan yang dibuat pemerintah sehingga terkadang sikap acuh tak acuh diperlihatkan oleh masyarakat dan tindakan melawan aparat yang dilakukan oleh para pedagang tak dapat terhindarkan.

Senada wawancara dengan salah 
Tersedia Online di http://journal.unismuh.ac.id/index.php/otoritas

Otoritas : Jurnal Ilmu Pemerintahan, 6 (1), April 2016, 40

satu pengunjung di Pasar Minasamaupa yang mengatakan bahwa:

"Upaya yang dilakukan oleh pemerintah dalam melaksanakan penataan pedagang kaki lima di Pasar Minasamaupa sebenarnya sudah benar adanya. Namun, tindakan yang biasanya diperlihatkan oleh pedagang mencerminkan bahwa kesadaran mereka masih minim akan peraturan yang ada." (Wawancara. AA, 21 Juli 2015).

Berdasarkan hasil wawancara di atas menunjukkan bahwa memang partisipasi masyarakat masih minim tentang peraturan tentang penataan pedagang kaki lima sehingga dalam penerapannya banyak masyarakat yang tidak mematuhi aturan tersebut.

\section{Kesimpulan}

Peran Pemerintah Daerah Kabupaten Gowa dalam pelaksanaan penataan pedagang kaki lima di Pasar Minasamaupa sudah cukup berperan, dimana Pemerintah Daerah melaksanakan berdasarkan Peraturan Daerah Nomor 5 Tahun 2009 yaitu melakukan penataan tempat usaha dengan memberikan tempat usaha bagi Pedagang Kaki Lima berupa kios-kios yang telah ditata berdasarkan jenis jualan pedagang.

Selanjutnya melakukan pembinaan kepada pedagang untuk kepentingan pengembangan usaha dan peningkatan kesejahteraan pedagang kaki lima dan melakukan pengawasan karena melihat banyaknya pedagang kaki lima yang masih menempati tempat mereka sebelum direlokasi.

Faktor-faktor yang mendukung pelaksanaan penataan pedagang kaki lima di Pasar Minasamaupa yaitu adanya Peraturan Daerah Kabupaten Gowa Nomor 5 Tahun 2009 tentang Penataan dan Pembinaan Pedagang Kaki Lima untuk menciptakan kesejahteraan masyarakat dan demi terciptanya Kabupaten Gowa yang aman, nyaman dan produktif. Sedangkan faktor penghambat dalam palaksanaan penataan pedagang kaki lima di Pasar Minasamaupa yaitu rendahnya partisipasi pedagang dalam mematuhi peraturan yang di terapkan.

Kemudian disarankan agar pemerintah daerah mengambil tindakan untuk mencegah bertambahnya pedagang kaki lima baru di lokasi yang telah ditata.

\section{Ucapan Terima Kasih}

Kami mengucapkan terima kasih sebesar-besarnya kepada pihak-pihak yang terlibat dalam penelitian dan penulisan karya ilmiah ini, terkhusus kepada Civitas Akademika Program Studi Ilmu Pemerintahan, Fakultas Ilmu Sosial dan Ilmu Politik, Universitas Muhamadiyah Makassar dan instansi yang menjadi tempat kami melakukan penelitian.

\section{Daftar Pustaka}

Ahkam, H. (2015). Program Penataan Pedagang Kaki Lima (PKL) di Wilayah Perkotaan (Studi Pada Pemerintah Daerah Kabupaten Bondowoso). Jurnal Administrasi Publik, 3, (9), 1548-1552.

Dewi, P., Yanuardi, Y. (2013). Implementasi Kebijakan Penataan Pedagang Kaki Lima Di Kawasan Malioboro Yogyakarta. Jurnal Adinegara, 7, (1), 1-14.

Erlinda, R.D., Sutji, A.B.D.D., Indrayati, R. (2014). Kajian Yuridis Tentang Izin Pedagang Kaki Lima di Jalan Jawa Untuk Mewujudkan Penyelenggaraan Pemerintahan Yang Baik (Good Governance) di Wilayah Kabupaten Jember. E-Journal Lentera Hukum, 1, (1), 33-42.

Evita, E. (2013). Implementasi Kebijakan Penataan Pedagang Kaki Lima (Studi Pada Batu Tourism Center Di Kota Batu). Jurnal Administrasi Publik, 1, (5), 943-952.

Karafir, K. (2007). Pembangunan Masyarakat. Yogyakarta: Liberty.

Nugroho, R. (2009). Public Policy. Jakarta: 
Tersedia Online di http://journal.unismuh.ac.id/index.php/otoritas

Otoritas : Jurnal Ilmu Pemerintahan, 6 (1), April 2016, 41

Elexmedia Komputindo.

Peraturan Daerah (Perda) Kabupaten Gowa Nomor 5 Tahun 2009 tentang Penataan dan Pembinaan Pedagang Kaki Lima.

Sugiyono, S. (2013). Metode Penelitian Kuantitatif Kualitatif dan $R \& D$. Bandung: Alfabeta.

Sedarmayanti, S. (2010). Manajemen Sumber Daya Manusia: Reformasi Birokrasi Dan Manajemen Pegawai Negeri Sipil. Bandung: PT. Rafika
Aditama.

Soekanto, S. (2009). Peranan Sosiologi Suatu Pengantar. Jakarta: Rajawali Pers. 